\title{
Problems of Implementation of Management Accounting Automation in Russia
}

\author{
Azmitov R.R. ${ }^{a}$ \\ Korabelnikova L.L. ${ }^{b}$ \\ a, b Kazan Federal University, Institute of Management, Economics and Finance, Kremlevskaya St, 18, Kazan, 420008, Russia \\ Emails: RRAzmitov@kpfu.ru
}

\section{Doi:10.5901/mjss.2015.v6n1s3p384}

\section{Abstract}

The paper considers practical issues of management accounting recording by domestic enterprise. Possibilities and reasonable steps for major implementation of management accounting on the basis of its automation are investigated. Actual theoretical and practical works on management accounting consider necessity of management accounting recording by domestic enterprise, highlighting fundamentals of accounting information building. Efficient economic entity management is impossible without management accounting, automation of which enables facilitation of output and making reasonable policy decisions even with minimal functions set.

Keywords: management accounting, management accounting automation, efficiency of financial and operational activities

\section{Introduction}

Despite antiquity of management accounting occurrence in Russia, it has still not gained widespread currency. Such authors as V. B. Iveshkevitch, V. F. Paliy, A. D. Sheremet were the first developers of domestic management accounting.

As opposed to foreign practices where management accounting has the major role [1], domestic practice focuses on maintenance of financial and fiscal accounting[5].

How to increase the number of users of management accounting?

In this article we will try to gain insight into conditions interfering with such a positive type of accounting in the context of efficient financial and operational activities recording as management accounting.

\section{Theory}

As a result of modern works analysis[9], we can conclude that implementation of management accounting is possible and necessary for all businesses and organizations[8]. But currently the main users are large and extra large businesses [6], but at the same time, no one denies need for management accounting in small organizations. This way, for example, economic entities can, by using proper formed management accounting, validate reasonability of order placing [9] and profit margin determination of different segments (type of products, activities, customers) and making decisions on price determination[10], assortment policy (manufacturing and sales organizations), or key directions of development formation (including service entities comprising tertiary institutions) [3, 11].

It is some authors' opinion (V. B. Ivashkevitch, A. U. Sokolov) that the main problem of setting management accounting is high cost associated with necessity of engagement of top-ranked subject-matter experts, that requires considerable financial expenses and is obviously the main limiting factor of widespread development of this type of accounting in our country[4].

The only one cure for such a situation may be development of automated consistent software, considering peculiar properties of different industries, but being inexpensive for developers and users, that makes it possible to expand application and areas of use of management accounting methods as part of formation and evaluation of management information system indexes.

At the present day there is a number of software products ("Management Accounting" by "7Soft", "Management Accounting" by "First BIT" etc.), the use of which requires enrichment experiences that often accountants are lack for. In addition to this, introduction and using of this software cost may be hundreds of thousands rubles, that is enormous for the majority of small and micro-enterprises.

Certainly, reduction to practice of management accounting will cause reaction of accountants (training, retraining etc.) and administration (salary increase, hiring new employees), but ultimately will help improving economic skills of all 
participants. That will be useful for all market participants, including government [2], by increasing efficiency of financial and operational activities and thus enhancing of fiscal payments, capital turnover and therefore decline in inflation, as opposed to current plans and sometimes real bills on burden of taxation for businesses and organizations [7].

The use of 1:C-based software as one of the most widely replicated software on the domestic market by way of simplification of management accounting implementation is possible, with its user-defined additional features set.

It is possible to integrate an additional tab for generating management accounting data and statutory accountingbased reports, with accounting being the basis of software product in most cases. This procedure will require some adjustments in accounting policy, generated for accounting purposes.

Using accounting programs that are "usual" for accountants enables reducing financial expenses of organizations and time expenditure of accountants for management accounting implementation and recording through a usual interface.

\section{Results}

At the present day, state fiscal policy, deficiency of government programs on development of the management accounting (unlike financial accounting, management accounting is not regulated, thus necessity of its maintenance is at management discretion) forbids acceleration of economic entities' management consciousness of demand in practical integration of management accounting.

Besides, modern educational programs for accountants are focused on formation of accounting program operator profession by means of increase in number of hours for accounting automation, together with decrease in number of hours allowed for classes on accounting (financial accounting) and management accounting. As the result, it may lead to easy substitution of experts (accountants and executives) by operators coming inexpensive significantly for businesses for payment, but at the same time, incapable of program error checking and control.

\section{Conclusions}

As can be seen from the above, we emphasize that it is essential to get state support for management accounting as profession and software engineers in a part of creating programs on management accounting automation and market promotion, and with an entities' management proper treatment of management accounting recording and automation.

\section{References}

Clarke, P., Tagoe, N. Strategic management accounting - Do we need it? // Accountancy Ireland, 2002. - p.10.

Gill, J. Management accounting in the public sector // Chartered accountants journal of New Zealand 82 (2), 2003. - p.62.

Kaspina, R.G., Khapugina, L.S., Zakirov, E.A. Employment of activity-based costing in the process of company business model generation // Life Science Journal 11 (SPEC. ISSUE 8), 78, 2014. - pp. 356-359

Kaspina, R. G., Khapugina, L.S., Zakirov, E.A. Interrelation of Company's Business Model Structure and Information Disclosed in Management Reporting // Life Science Journal, 11 (12), 2014. pp. 778-780.

Kaspina, R.G., Plotnikova, L.A. Accounting of external economic activity of Russian companies: Experience and difficulties // Life Science Journal, 11 (11), 2014. pp. 108-111.

Markaryan, S.E., Snetkova, T.A., Khairullina, D.V.Administrative aspects of accounting organization. Russian experience and problems // Life Science Journal 11 (SPEC. ISSUE 8), 22, 2014. - pp. 107-111

Needles, Jr., Shigaev, A.I., Powers, M., Frigo,M.L. Operating characteristics of high performance companies: Strategic direction for management // Studies in Managerial and Financial Accounting, 28, 2014. pp. 25-51.

Panasyuk, M.V., Dzasaeva, R.D., Shaidullin, R.N., Anopchenko, T.Y. Problems of modernization of the health economics in the russian regions // World Applied Sciences Journal, 27(13), 2013, 154-158.

Isaeva, T.N., Safiullin, L.N., Bagautdinova, N.G., Shaidullin, R.N. Aspects of a multi-level study of competitive performance of objects and subjects of economic management // World Applied Sciences Journal, 27(13), 2013, 116-119.

Shigaev, A.I. Strategy and integrated financial ratio performance measures: A longitudinal multi-country study of high performance companies. Performance Measurement and Management Control: Innovative Concepts and Practices // Studies in Managerial and Financial Accounting, 20, 2010. pp. 211-252.

Yakupova, N., Absalyamova, S. Assessment and management of enterprise value // SGEM International Multidisciplinary Scientific Conferences on Social Sciences and Arts. SGEM Conference on Political Sciences Law, Finance Economics \& Tourism. Volume IV, 2014. pp. 51-58.

Zaitseva, N.N. About management accounting and higher education institution management // Bulletin of the university 2(1), 2008. pp. 25-28

Safiullin L.N., Fatkhiev A.M., Safiullina L.M. Projected trends and problems of education. Life Science Journal $2014 ; 11$ (6s): $384-387$. 